Man and Nature

MAN AND NATURE

L'homme et la nature

L'HOMME ET LA NATURE

\title{
'This Pestiferous Reading': The Social Basis of Reaction Against The Novel in Late Eighteenth- and Early Nineteenth-Century Britain
}

\section{Gary Kelly}

Volume 4, 1985

URI : https://id.erudit.org/iderudit/1011845ar

DOI : https://doi.org/10.7202/1011845ar

Aller au sommaire du numéro

Éditeur(s)

Canadian Society for Eighteenth-Century Studies / Société canadienne d'étude du dix-huitième siècle

ISSN

0824-3298 (imprimé)

1927-8810 (numérique)

Découvrir la revue

Citer cet article

Kelly, G. (1985). 'This Pestiferous Reading': The Social Basis of Reaction Against The Novel in Late Eighteenth- and Early Nineteenth-Century Britain. Man and Nature / L'homme et la nature, 4, 183-194. https://doi.org/10.7202/1011845ar

Copyright (c) Canadian Society for Eighteenth-Century Studies / Sociéte canadienne d'étude du dix-huitième siècle, 1985
Ce document est protégé par la loi sur le droit d'auteur. L'utilisation des services d'Érudit (y compris la reproduction) est assujettie à sa politique d'utilisation que vous pouvez consulter en ligne.

https://apropos.erudit.org/fr/usagers/politique-dutilisation/ 


\section{This Pestiferous Reading: The Social Basis of Reaction Against The Novel in Late Eighteenth- and Early Nineteenth-Century Britain}

Novel reading was disapproved of in Britain from the seventeenth century at least, but never more so than in the late eighteenth and early nineteenth centuries. Not until the huge commercial success of, and substantial critical acclaim for, the novels of the 'Wizard of the North,' Sir Walter Scott, did the tide of disapproval begin to slacken. This much is clear from studies by Joseph Heidler, Joyce Tompkins, W.H. Rogers, W.F. Gallaway Jr., John Tinnon Taylor, and others. ${ }^{1}$ These scholars explain early opposition to the novel as the result of justified if somewhat narrow-minded abhorrence of the moral deficiencies of most novels between Smollett and Scott, and equally justified disappointment at these novels' artistic deficiencies: only when a writer with artistic talent, conservative moral and social values, and wide general knowledge came along could readers and critics alike see the true potential of the novel form. These historians of the novel and reaction to it do not, however, attempt to explain moral and aesthetic criticisms of the novel in terms of the important social changes and conflicts of the period. In this paper, using typical comments from the critical and periodical literature of the day (comments similar to ones cited by Heidler, Taylor and the others), I will argue that the critical reaction against the novel in the period 1770 to 
1830 reflected and expressed particular social and ideological tensions in the main body of consumers of the novel, namely the professional and upper-middle classes.

In the second half of the eighteenth century, the increased prosperity of the gentry and of the professional and upper middle classes, increased population and concentration of that population in towns with a greatly diversified and independent cultural life, and the commercialization of leisure and culture in various kinds of fashionable consumption and social emulation, all resulted in new turns in the ideological selfconsciousness and self-confidence of the new leaders in town life - the upper-middle classes and especially the professional people. ${ }^{2}$ But even though the professional classes in particular enjoyed a remarkable increase in numbers, variety, prosperity, independence, and social mobility from the late seventeenth century on, their cultural and ideological models remained principally those of the landed gentry until late in the eighteenth century. ${ }^{3}$ The resulting tensions and contradictions of selfconfidence and social emulation can be seen clearly in the critical reaction to one of the period's most important forms of social instruction and fashionable consumption, novel reading.

There is plenty of testimony to the fact that reading in general had become widespread and fashionable amongst the literate and well-to-do in late eighteenth-century Britain. ${ }^{4}$ Furthermore, professional people are perhaps by definition devoted to the culture of the book. However, the books which they and other middle-class people seemed to want to read were not for the most part 'solid reading,' but rather novels, and novels had, since the seventeenth century, been associated mainly with the values and culture of the aristocracy and gentry. Love, honour, intrigue, gallantry, and property - these were the themes of the short fiction or 'novel' of the late seventeenth century, derived from the French nouvelle of a slightly earlier period. ${ }^{5}$ This kind of fiction reflected or embodied the values of an aristocratic court culture, but one increasingly diffused, socially and ideologically. More importantly, however, it was the kind of fiction which would appeal to the romantic and social aspirations of those in lower levels of society, especially those in the affluent and socially mobile professional middle classes who were still penetrated by the cultural and ideological hegemony of the aristocracy and gentry. In the later eighteenth century the older short form of the nouvelle galante was extended to suit the circulating libraries' practice of renting books by the volume rather than by title, and this form of the novel and of novel distribution made possible the rapid development of a new fashion, novel reading, amongst the professional and middle classes. Novels were produced in large numbers, as articles of fashionable consumption rather 
than permanent possession; most of the print run of any novel was purchased by proprietors of circulating libraries, many of which were situated in towns or parts of a town known primarily as places of fashionable resort, and novels were accordingly quite expensive. ${ }^{6}$ It was only the reprints of the 'classics' of fiction which were produced in a form and at a price which made the articles suitable for inclusion in a personal library. Even so, a large part of the print run of many of these - and they were increasingly common after the ending of perpetual copyright in 1774 - also ended up in circulation libraries.

However, the main stock-in-trade of the circulating libraries was 'modern novels.' These were developments, in theme and form, of the seventeenth-century novels; that is, they were mostly novels of manners in which love and property and social status were the principal matters of plot and conflict, and in which some kind of resolution through matrimony was a desired end. Central characters tended to be in fact genteel, or else to possess transmuted gentility in the form of 'sensibility,' and the novels were often set in fashionable society, or used it as a reference point. ${ }^{7}$ Of course there were also many novels which embodied the values and beliefs of the ordinary middle classes and of the superior artisans and masters of trade. It is also true that the circulating libraries, their 'trash,' and their patrons spanned a wide range, from the elegant establishments, well-bound and tastefully-labelled triple-deckers, and genteel patrons, all to be found in Bath or Cheltenham or London's Bond Street (both Old and New), to the village general shop with its countershelf of frayed and dirty novels, odd volumes, chapbooks, and stray issues of magazines, expectantly pawed over by apprentices, tradesmen, housewives, and servants. No doubt there were more of the latter than of the former, scattered throughout the three kingdoms, but in fact it was the triple-decker 'circulating-library novel' which dominated the market, and which drew the hostility of reviewers and critics, writers of letters to magazine editors, and commentators on Britain's changing social and cultural life. The kind of observation found in a book entitled The Evils of Adultery and Prostitution (1792) was not uncommon:

A ... cause of the profligacy of the present age, is that mass of novels and romances which people of all ranks and ages do so greedily devour. This is a new species of entertainment, almost totally unknown to former ages .... The great encouragement given to productions of this kind is a great mark of the frivolousness and effeminacy of the present age, and a striking characteristic of their manners....

... Such as devote their time to this species of reading, are seldom capable of at- 
tending to books where solid instruction is conveyed; they never can be expected to relish that reading which requires any degree of attention or any stretch of thought. This light and airy reading gives a play to the fancy and imagination: it affords amusement, but furnishes neither knowledge nor instruction. But the worst effect: novels dress out vice in pleasing colours, gild over all its deformities, and thus insensibly instil the deadly poison into the thoughtless and unwary heart. The dissipated rake, who glories in his debaucheries, is painted often as humane, generous, and benevolent; whilst the heedless female, for the sake of these accomplishments, forgets his want of principles, his diseased body, and his rotten heart .... Many young girls, from morning to night, hang over this pestiferous reading, to the neglect of industry, health, proper exercise, and to the ruin both of body and soul. And this pernicious practice is not confined to girls only of fortune, but extends to every age and rank; and there are instances even of servant girls who are well acquainted with all the fashionable romances .... The increase of novels will help to account for the increase of prostitution and for the numerous adulteries and elopements that we hear of in the different parts of the kingdom. ${ }^{8}$

None of the points made here was being made for the first time. Others in the 1770 's, 80 's, and 90 's had noticed the novelty of the novel's popularity, its penetration to almost every level of society, the special fondness of female readers for it, its tendency to deal with romance and with fascinating but dangerous upper-class rakes and their cousins, the natural gentlemen of feeling. Many others in these decades had argued that the novel over-stimulated the imagination, set readers imitating fiction in their own lives, and usurped the place of useful and edifying reading. And at least some others had seen the novel as striking at the heart of hearth and home. But it is the persistent transformation of social into moral criticism which is most obvious here. Condemning novels for their corrupting effect on the minds and morals of their readers, and then the linking of this effect to dire social consequences, were the usual grounds of attack on novels in the late eighteenth century. As 'Eusebius' wrote in the Gentleman's Magazine for November 1797:

A young woman, who employs her time in reading novels, will never find amusement in any other sort of books. Her mind will be soon debauched by licentious description, and lascivious images; and she will, consequently, remain the same frivolous and insignificant creature through life; her mind will become a magazine of trifles and follies, or rather impure and wanton ideas. Her favourite novels will never teach her the social virtues, the qualifications of domestic life, the principles of her native language, history, geography, 
morality, the precepts of Christianity, or any other useful science. (vol. 67, p. 912)

This emphasis on utility, a kind of moral-intellectual criticism, is found increasingly in the opposition to the novel in the late eighteenth century, and draws on a long tradition of suspicion of mere entertainment amongst the middle class, especially puritans and Dissenters. This suspiciousness is joined to an increasing concern that reading be practical and serve personal and social industriousness. Opponents of novel reading claimed that it interfered with these pursuits. Even after Scott had seemed to show many critics, and many male, if not female readers, that the novel could indeed be useful reading, a provincial magazine such as the Kaleidoscope; or, Literary and Scientific Mirror of Liverpool would suppose its readers would be interested in the true story of a young businessman who became so addicted to novel-reading that he went bankrupt. 'Such was the real career of a novel reader,' the magazine warned. 'Instead of now adorning the first circles of society, he is a poor wretched outcast, reduced to beggary and want, - the consequence of this one failing, which, if properly combatted in its infancy, might easily have been overcome' (21 August 1821, p. 54).

The writer of this must have struck a responsive chord; only two weeks later another writer in the same magazine compared excessive novel reading to excessive drinking: 'As the strongest bodily powers are not proof against the pernicious effects of the excessive use of ardent spirits; so the strongest mind is unable to resist the enervating effects of an unlimited indulgence in novel-reading.' This writer too saw novel reading as a threat to industrious habits, for in novels 'the reader finds characters who acquire all manner of knowledge without any trouble, and become rich without finding it necessary to be industrious. He becomes disgusted with the labour which the acquisition of any useful knowledge costs him, and begins to think that only dull, plodding fellows ought to be industrious' (4 September 1821, p. 65). If by the time this was written the tide of opinion had begun to turn in favour of novels in the intellectual and sophisticated circles of London and Edinburgh, in the heartland of nineteenth-century trade, commerce, and industry, novel reading was still seen by some at least as contrary to industriousness, and thus to the new industrial spirit.

Opposition such as this, however, was only the last development of a social and class-based hostility to the novel which had been the main undercurrent of criticism for decades. As I said at the beginning, the novel had been associated with aristocratic or even court values and culture ever since the Restoration. Conventional late eighteenth-century 
histories of the rise of prose fiction traced the 'modern novel' back to the short 'novel' of intrigue and gallantry written by Aphra Behn and others, and this was traced in turn to the French 'nouvelle' which was seen as the fruit of the long courtly prose romances of the late renaissance. One of the most influential attacks on the 'modern novel' in Britain in the latter part of the eighteenth century clearly associated it with what was supposed to be the decadent libertine aristocratic culture of contemporary France and of Restoration England. Vicesimus Knox's essay 'On Novel Reading,' published in 1779 and reprinted frequently thereafter, began with the observation that, 'If it is true, that the present age is more corrupt than the preceding, the great multiplication of Novels probably contributes to its degeneracy. Fifty years ago there was scarcely a Novel in the kingdom' (Essays Moral and Literary, vol. 2, 1779, p. 185). Knox tended to approve of romances, because he thought they set forth ideal models for imitation.

But the multitude of memoirs, private histories, and curious anecdotes, imported from our neighbouring land of libertinism, have seldom any thing to recommend them to perusal but their profligacy. Yet these, adorned with specious titles, and a pert vivacity of language, have found their way to the circulating libraries, and are obtruded on the attention of every age and rank. (p. 188)

Knox saw the native productions of his own time as directly descended from the last age of libertinism in Britain itself, as he added, 'The English press has teemed with similar original productions. The effects of that coarse taste introduced in the reign of Charles the Second, have scarcely yet decreased.'

Critics, historians, and moral writers such as Knox were aware that there had been important distinctions between the novel and the romance, and in the later eighteenth century some of them tried to develop those distinctions in order to discriminate amongst the plethora of fiction of their own day. On the whole, however, both the novel and the romance remained associated with aristocratic court culture. Eight years after Knox's essay, for example, the young George Canning, writing in his periodical The Microcosm, argued that the 'modern novel' was simply a transmutation of the chivalric romance:

... the Novel [he wrote] is but a more modern modification of the same ingredients which constitute the Romance; and ... a recipe for the one may be equally serviceable for the composition of the other. 
A Romance (generally speaking) consists of a number of strange events, with a Hero in the middle of them; who, being an adventurous Knight, wades through them to one grand design, namely, the emancipation of some captive Princess, from the oppression of a merciless Giant; for the accomplishment of which purpose he must set at nought the incantations of the caitiff magician; must scale the ramparts of his castle; and baffle the vigilance of the female dragon, to whose custody his Heroine is committed.

Foreign as they may at first seem from the purpose of a Novel, we shall find, upon a little examination, that these are in fact the very circumstances, upon which the generality of them are built; modernized indeed in some degree by the trifling transformations of merciless Giants into austere Guardians, and of she-dragons into Maiden Aunts. We must be contented also that the Heroine, though retaining her tenderness, be divested of her royalty; and in the Hero we must give up the Knight-errant for the accomplished Fine Gentleman. (17 May 1787)

Half-serious this may be; but it certainly rests upon the assumption that the stuff of novels is sentimental romance. The sentimentalism of novels was a common objection to them, but few of the objecters allowed themselves to be as light-hearted on the subject as Canning did. As we have seen already, in the extract from The Evils of Adultery and Prostitution, published only five years after Canning's essay, sensibility was regarded by alarmed moralists as merely a transformed version of aristocratic libertinism. But an essay 'On the dangerous influence of Novels' published in the Biographical and Imperial Magazine for March 1790 had already made the point most forcibly when it declared:

The enthusiast, whose love of virtue is as yet uncorrupted by the thoughtless follies of fashion, whose reflections are not as yet dissipated by riot, or drowned in dissipation, - and whose heart is not hitherto abandoned to sensuality, reprobates with honest ardour the increasing force which these compositions generally lend to the already too luxuriant passions ... he regards with generous indignation the specious ornaments with which fashionable vices are generally gilded, in these fictitious histories ....

... Can he view the dissipated pursuits of self-gratification veiled in the robe of generosity, and not execrate the fatal deception? - Can he, without contempt, hear thoughtless extravagance proclaimed as the argument of a good heart or the wanton cruelties of headless [i.e. heedless] dissipation announced as arguments of an open disposition - while the neglect of every moral, and con- 
tempt of every religious duty, are described as the characteristics of a generous soul? (Vol. 3, pp. 171-2)

The danger, as far as such critics were concerned, was that the values of decadent aristocratic culture, such as libertinism or sentimentalism, would penetrate the lives and consciousness of those below them in society. In a one-act play called Half an Hour after Supper, performed at the Haymarket Theatre in May 1789 and every season thereafter until 1798 , the wives, sons, daughters, and servants of honest tradesmen are all shown attempting to imitate the romantic airs and adventures, the fashionable vices depicted in novels. In 1793 a reader wrote to the editor of the Gentleman's Magazine to denounce the novel's preoccupation with fashionable vices and libertine loves: This contagion is the more to be dreaded as it daily spreads through all ranks of people; and Miss the Taylor's Daughter talks now as familiarly, to her confident [sic] Miss Staytape, of swains and sentiments as the accomplished Dames of genteel life' (vol. 63, p. 294). Twelve years later, in October 1805, the same magazine argued that the pleasure of novel-reading consists in the reader's being introduced into the acquaintance of a class of personages of superior wealth and rank, of extraordinary virtues and extravagant vices, with whom he is not likely to become familiar in any other way' (vol. 75, p. 912).

It is true, of course, that there were a number of serious attempts to defend the novel in late eighteenth-century Britain. However, these defenders almost all admitted that whatever potential the novel might have for purveying instruction and knowledge it was in practice a vehicle for upper-class values and vices. Another common approach was to discriminate the 'modern novel' from the 'modern romance,' and then to blame the latter for all the fashionable follies. George Canning, for example, whose facetious analysis of the transformation of old romance into 'modern novel' has already been referred to, seriously advanced in the same essay a set of distinctions between the two forms which was a mixture of formal and moral values:

The Fiction of Romance is restricted by no fetters of reason, or of truth; but gives a loose to lawless imagination, and transgresses at will the bounds of time and place, of nature, and possibility. The fiction of the other on the contrary is shackled with a thousand restraints; is checked in her most rapid progress by the barriers of reason; and bounded in her most excursive flights by the limits of probability. (p. 296)

Ten years later in 1797 a reader of the Monthly Magazine, which tended 
to represent the values of liberal professionals, professional intellectuals, and liberal Dissent, criticized the lack of discrimination of those suffering from what he or she called 'novellophobia,' and advanced a threefold generic distinction in 'romance' (which he or she used interchangeably for the term 'novel') in order to single out those kinds of novels which might be useful. First there was 'the historic romance, in which there is a mixture of truth and fable, of novel and history'; this, the reader thought, was probably only an attempt to avoid the 'odium' attached to most novels, and therefore not to be taken too seriously. Then there was 'the hobgoblin-romance,' or gothic novel, dismissed as mere trash. However there was one form of the novel which was of great value:

The highest species of romance is surely that which, at once, exhibits just views of human nature and of real life, which mingles reasoning and philosophy, with strokes of humour, that play upon the fancy, and with pathos, which touches the heart. Who can withhold applause from [John Moore's] Zeluco, which Gibbon justly calls, 'the first philosophical romance of the present age?' (vol. 4, November 1797, p. 348)

For this reader the novel ought to be a vehicle for social and political information and enlightenment, as it was for example in the recent novels of the 'English Jacobins':

The dialogues in Zeluco, passages in the philosophical romances of Bage, Holcroft, and some others, have probably diffused more liberal, and more just moral ideas, than could, in the same space of time, have been inculcated upon the public by a thousand sermons, or by as many dry political disquisitions. Persons who would never undertake the perusal of a formidable folio, and who have, perhaps, modestly deceived themselves into a belief that they have not talents for abstract speculation, or close reasoning, are in works of this instructive and amusing description, made to feel and acknowledge their own powers. They insensibly form a comparison between their own reasoning and that of the characters whose conversations they read; thus, without the appearance of study, they acquire clear ideas, they feel their curiosity awakened, and their appetite for moral and political knowledge insensibly increase. Those who are afraid of philosophy, when she speaks in the language of the schools, are glad of her acquaintance, and proud of being able to converse with her, when she talks plain prose. (p. 349)

Here was at least one person who saw the novel in a particular form as an important instrument in the spread of liberal enlightenment, which was 
implicitly therefore a weapon in the attack on the hegemony of the aristocracy and gentry.

The usual defence of the novel or of particular forms of the novel was more conservative and covert than this one, however, and concentrated on the novel's capacity for portrayal of individual life and domestic realism. This approach is rather an implicit rejection than an attack on the novel of fashionable life. Thus Robert Alves, in his Sketches of a History of Literature (1794), designed as a guide for the middle-class aspirant to literary culture, preferred history to fiction, as more solid and useful. 'Novel-writing, however,' he admitted, 'as containing the history of man in a private capacity, with his various peculiarities, foibles, and good qualities, may, though less solemn in its objects, become, in able hands, peculiarly interesting in detail, from those domestic incidents and peculiar situations which are more or less the lot of all' (p. 232). Three years later, in the Monthly Magazine for September 1797, Mary Hays, herself a friend of the 'English Jacobin' novelists and a member of the circle of William Godwin and Mary Wollstonecraft, also argued for the novel's superiority in depicting the ideal and unreal. 'The business of familiar narrative,' she wrote, adopting Samuel Johnson's term for prose fiction, 'should be to describe life and manners in real or probable situations, to delineate the human mind in its endless varieties, to develope the heart, to paint the passions, to trace the springs of action, to interest the imagination, exercise the affections, and awaken the powers of the mind. A good novel ought to be subservient to the purposes of truth and philosophy ...' (vol. 4, p. 181). This conception of the usefulness of the novel as an 'exercise' of thought and feeling, by means of domestic and psychological realism, was probably developed from Mary Wollstonecraft's ideas on the proper kind of literature for intellectual enlightenment and moral growth, and anticipated by just two months the praise of 'philosophical romance' cited earlier from the same magazine.

By the end of the eighteenth century the main lines of critical reaction to this new phenomenon in the worlds of fashion and letters, the 'circulating-library novel,' or 'modern novel,' had been established, and all of the main points had been registered and repeated between Vicesimus Knox's essay of 1779 and the Monthly Magazine essays of 1797. Novels were clearly associated with what was seen as decadent aristocratic culture; they inspired fantasies of social climbing, or imitation of sexually and financially extravagant fashionable follies; they obstructed useful learning, and even useful occupations; and like cheap imitations of fashionable articles of consumption they were often massproduced and shoddy. These were by far the most commonly expressed 
views, often by readers or amateur essayists who contributed their condemnations to the very magazines which were stuffed with the kind of fiction they condemned. On the other hand there were those who attempted to defend the novel, especially in the more serious liberal and intellectual magazines, and these defenders were occasionally serious novel-writers themselves, as in the case of Mary Mays. They tried to distinguish what they considered to be morally, intellectually, and socially valuable novels from those, the majority, which still embodied what they saw as decadent aristocratic culture. However, whether the novel was indiscriminately condemned as morally and intellectually corrupting, or was carefully discriminated from the romance, and then promoted as a vehicle for middle-class professional interests and ideals, the common factor was a fear of prose fiction being used to maintain or even to advance upper-class cultural and ideological hegemony. Puritanical conservatives and intellectual liberals both argued that the 'trash of the circulating libraries' made available to middle-class readers, and especially to women, fantasies of social climbing or of flirtation with aristocratic culture which were morally and socially corrupting. But they also consistently translated the clash of social codes into moral issues. Critics of the novel of whatever political persuasion represented real attempts to enforce some kind of ideological discipline amongst a newly emergent power in British society, one that would, after effecting a social and political coalition with the gentry, rule Britain down to the present. ${ }^{9}$ The late eighteenth-century critics of the 'modern novel,' whether they advocated suppression of novel reading altogether, or appropriation of the novel as an ideological weapon, refused to use the terms of class conflict and used moral terms instead, but all recognized the power of the novel to formulate and diffuse ideology throughout society. Appropriately, then, it was Sir Walter Scott who resolved the opposition to the novel which had been such a feature of late eighteenth-century cultural and social criticism. Scott, himself a gentrified professional, in the tradition of the Scottish law lairds, argued in novels of unprecedented popularity and critical approval for that coalition of professional gentry and gentrified professionals which already existed in Edinburgh ${ }^{10}$ and which would dominate Britain for the rest of the nineteenth century. Thereby Scott showed critics and readers alike what 'this pestiferous reading,' the 'modern' novel, could and would become - the central pillar of their social and ideological institution of literature.

GARY KELLY

University of Alberta 
Notes

1 Joseph Bunn Heidler, The History, from 1700 to 1800, of English Criticism of Prose Fiction (Urbana, Illinois: University of Illinois Press, 1928); J.M.S. Tompkins, The Popular Novel in England 1770-1800 (London: Constable, 1932); W.H. Rogers, 'The Reaction against Melodramatic Sentimentality in the English Novel,' PMLA, 49 (1934), 98-123; W.F. Gallaway, Jr., 'The Conservative Attitude toward Fiction, 1770-1830,' PMLA, 55 (1940), 1041-59; John Tinnon Taylor, Early Opposition to the English Novel (New York: Kings Crown Press, 1943).

2 On the rise of professionals, see Geoffrey Holmes, Augustan England. Professions, State and Society 1680-1730 (London and Boston: G. Allen \& Unwin, 1982); on the gentry, G.E. Mingay, The Gentry. The Rise and Fall of a Ruling Class (London and New York: Longman, 1976). On the commercialization of leisure and culture in relation to social change and emulation, Neil McKendrick, John Brewer, and J.H. Plumb, The Birth of a Consumer Society. The Commercialization of Eighteenth-century England (London: Europa, 1982).

3 This point was made by T.H. Marshall in The Recent History of Professionalism in Relation to Social Structure and Social Policy,' Canadian Journal of Economics and Political Science, 5 (1939).

4 A.S. Collins, The Profession of Letters. A Study of the Relation of Author to Patron, Publisher and Public, 1780-1832 (London: Routledge, 1928), pp. 81-4.

5 See Ioan Williams, The Idea of the Novel in Europe, 1600-1800 (New York, 1979), ch. 3.

6 On circulating libraries, see Devendra P. Varma, The Evergreen Tree of Diabolical Knowledge (Washington, 1972).

7 The best general account of the fiction of this period is still Tompkin's book, cited in n. 1.

8 (London: T. Vernor, 1792), pp. 51-4.

9 Martin Wiener, English Culture and the Decline of the Industrial Spirit (Cambridge and New York: Cambridge University Press, 1981); T.W. Heyck, The Transformation of Intellectual Life in Victorian England (New York: St. Martin's Press, 1982).

10 T.C. Smout, A History of the Scottish People 1560-1830 (n.p. 1969, 1972), pp. 342-55. 